\title{
The Status of Family Planning Methods among Married Women of Kavre District in Nepal
}

Sarita Bista*

\begin{abstract}
This study examines the information of family planning methods among currently married women of reproductive age group at Kavre District of Nepal. The main objective of the study is to find out the actual situation of family planning methods and the specific objective of the study are to identify the demographic determinants of currently use of family planning methods and to assess the reason for usage and non-usage of family planning methods in the study area. Moreover, this study also attempts to find out the actual sources of information of contraceptive devices in the study area. The study usages 200 respondenps from the three words of Ugratara VDC of the Kavre District of Nepal The main occupation of the respondents are agriculture and services. Among currently married women, 91 percent of the respondents are found to be familiaPr with at least one family planning method. Likewise, the major source of contraceptive devices of the respondents is found family planning clinics in the study area. The central purpose for using family planning methods is found for limiting the births. There are positive relationships between use of family planning methods and demographic variables.
\end{abstract}

Key words: Knowledge, practice, purpose, type \& contraceptive devices.

\section{Introduction}

According to the World Health Organization, family planning is defined as the ability of individuals and couples to anticipate and attain their desired number of children and the spacing and limiting of their births. Family planning not only improves women's chances of surviving pregnancy and child birth but also contributes to gender equality, better child health, and improved education outcomes including poverty reduction (WHO, 2010). The total population of Nepal is $26,494,504$ while the total household number is $5,42,7302$. If the population increases in the same ratio it will be doubled within 31 years (CBS, 2014). The principal cause to increase the population growth is continuous decline in death rate

\footnotetext{
*Ms. Sarita is a Faculty Associate of the Department of Population Studies, Patan Multiple Campus, TU, Nepal. Email: saritakarkibista@gmail.com
} 
and low use of family planning methods. Population growth is one of the serious problem in many developing countries. Nepal is also facing the same problem for attaining sustainable declination in fertility to reduce population burden. In spite of increased level of investment in population field during the five successive development plans, decline in level of fertility remained very low. To avoid such catastrophic situation the Government of Nepal is making every effort to promote the practice of family planning services.

The family planning program in Nepal is started with the established of family planning association of Nepal in 1959. In fact, Nepal was one of the first countries of South Asia where information about family planning is available through a non-government program. Since 1968 Government of Nepal has been actively involved in providing family planning services with the establishment of Nepal Family Planning and Maternal Child Health Project. Initially family planning program was integrated with maternal child health services (CBS, 2014).

The concept of family planning is shifted to reproductive health after the International Conference on Population and Development (ICPD) in 1994. After this conference, the family planning is considered as a major component of reproductive health. The conference stated that the aim of family planning program is to inspire couples and individuals to decide freely and responsively the number and spacing if their children and to ensure informed choices and make available of full range of safe and effective methods. The success of population education and family planning program in a variety of setting demonstrates that informed individuals everywhere can and will act responsively in the light of their own needs and those of their families and communities (UN, 1995).

Family planning is one of the priority program of Government of Nepal. It is also considered as a component of reproductive health package and essential health care services of Nepal Health Sector Program II (2010-2015), National Family Planning Costed Implementation Plan 2015-2021, Nepal Health Sector Strategy 2015-2020 (NHSS) and the Government of Nepal's commitments to family planning in 2020. In Nepal, the information and services of contraceptive devices are being provided through government, non-governmental organizations, private sectors, and social marketing. In government health system, currently, short acting reversible contraceptive methods such as male condoms, oral pills and injectable are provided on a regular basis through Primary Health Care Centres, Health Posts and Primary Health Care Outreach Clinics. Female Community Health Volunteers provide information and education to community people and distribute condoms and resupply oral contraceptive pills. Long acting reversible contraceptive services such as IUCD and implants are available only at limited number of hospitals (MoHP, 2014). 


\section{Objectives}

The main objective of this study is to examine the status of contraceptive devices among married women of the study area. The specific objectives of the study are to identify the knowledge of the sources of family planning methods and the aim of using of family planning methods in the study area.

\section{Statement of the Problem}

Population growth is one of the serious problems in many developing countries. Nepal is also not free from this very problem. Nepal is facing the problem of attaining sustainable declination in fertility to reduce population burden. In spite of increased level of investment in population field during the five successive development plans, decline in level of fertility remained very low. Continuous high population growth in Nepal is threatening to engulf the developmental achievements of the country. To avoid such catastrophic situation, the Government of Nepal is making every effort to promote family planning practices. The growth rate of population of Nepal is found 1.35 percent per year in 2011(CBS, 2014).

The trend of high fertility is observed in Nepal which is because of early marriage, early conception and lack of contraceptive knowledge and its usages. The contraceptive prevalence rate was obtained 24 percent in 1994 (NFHS, 1991) and it increased to 29.9 percent in 1997 and 39 percent in 2001 and 45.3 percent in 2011. Among all currently married women, although the rate is still low, the question arises why there is still low use of contraceptive devices. The knowledge of family planning methods (at least one) was found 21.3 percent in 1976, it was increased 92.7 percent in 1991 and 98.3 percent in 1996. Family health survey has shown that 98.3 percent of currently married women have knowledge of at least one of the modern family planning method. Family planning services are also provided at the grass root level not by government agencies but by number of non-government organization. Some of the well-known non-government organizations include contraceptive retails sales company and United Mission to Nepal. Beside these organizations, other Non-governmental Organization are also providing this services.

\section{Justification}

The study tries to reveal the existing knowledge and practice of family planning methods among the married women of reproductive age group of Kavre District, Nepal. Various literature shows that many women are not using contraceptive devices in our country. Though, it is also found that knowledge of family planning devices is found universal. 
The study in the area has also found out that women involved in out-door employment got lower fertility than the women were in indoor activities. Women are the main cause who play vital role in reproductive behaviour that is why special focus should be given in empowering women and mostly women need to be encouraged for outdoor jobs. The study also clarifies that accessibility of contraceptives encouraged couples to accept them that is why concern authorities should be aware in managing proper supply of family planning devices. This study has conducted the reasons of low use of contraceptive devices in Kavre District of Nepal. Thus, this result would be helpful to concerned local authorities and policy markers to make plan and policy in the study area.

\section{Methodology}

The present study has been conducted among currently married women aged 15-49 years resident of different three wards of Ugratara VDC of the Kavre District of Nepal. The study attempts to find out the status of family planning methods among married women in this district. This study is based on descriptive as well as exploratory research design which may consider as an appropriate and best for the analysis of this type of research work. This study is exploratory as it makes an attempt to explore the process of study area. In this study, 200 respondents are interviewed from the 100 selected households of the study area. The study has conducted by using simple random sampling method. This study is mainly based on primary sources of data. Secondary sources of data are taken from published and unpublished reports, research studies and articles by different researchers, line agencies, governmental and non-governmental organizations.

\section{Interpretation of the Data and Results}

\section{Age of the Respondents}

Respondent's age is an important factur to determine the contraceptive behaviour because only females of reproductive age groups can bear child or reproducing of children directly related to the female age groups. 
Table-1: Distribution of the respondents by five year age groups of women, 2015

\begin{tabular}{|c|c|c|}
\hline Age Group & Number & Percent \\
\hline $15-19$ & 84 & 42.0 \\
\hline $20-24$ & 90 & 45.0 \\
\hline $25-29$ & 10 & 5.0 \\
\hline $30-34$ & 5 & 2.5 \\
\hline $35-39$ & 7 & 3.5 \\
\hline $40-49$ & 4 & 2.0 \\
\hline Total & 200 & 100.0 \\
\hline
\end{tabular}

Source: Field Survey, 2015

Table 1 shows that the distribution of respondents by 5 years age group of women. This table also exhibits that the highest number of respondents belongs to age group of 2024 years (45\%), followed by age group 15-19 years (42\%), age group of 25-29 years (5\%), age group of $35-39$ years $(3.5 \%)$, age group of $30-34$ years $(2.5 \%)$ and only less percentage of the respondents ( $2 \%$ ) has found in the age group of $40-49$ years in the study area.

\section{Age at First Birth of Women and Children Ever Born}

Those who bear the children at early ages are likely to bear more children than that of the women who bear the children in their late ages. Number of the children determines the use and non-use of contraception and desire for children. If there are already a desired number of children to women, they are likely to use long term birth spacing methods for permanent method of contraception. 
Table-2: Distribution of respondents by age at first birth of women and number of living children, 2015

\begin{tabular}{|c|c|c|}
\hline 1. Age at first birth of women & Number & Percent \\
\hline $15-19$ & 84 & 42.0 \\
\hline $20-24$ & 100 & 50.0 \\
\hline $25-29$ & 16 & 8.0 \\
\hline Total & 200 & 100.0 \\
\hline 2. Children ever born & Number & 18.0 \\
\hline 1 & 36 & 39.0 \\
\hline 2 & 78 & 16.0 \\
\hline 3 & 32 & 13.0 \\
\hline 4 & 26 & 14.0 \\
\hline 5 and above & 28 & 100.0 \\
\hline Total & 200 & Percent \\
\hline
\end{tabular}

Source: Field Survey, 2015

Table 2 shows that the highest number of the respondents (39\%) have two children ever born, followed by one children ever born (18\%), three children ever born (16\%) five and above (14\%) and only less percentage of the respondents $(13 \%)$ have four children ever born in the study area. This table also exhibits that the highest number of women $(50 \%)$ have given birth to their first child at age group of 20-24 years, followed by the respondents' age group of 15-19 years (42\%) and only less percentage of women ( $8 \%$ ) have given birth to their first child at age group of 25-29 years in the study area.

\section{Sources of Contraceptive Devices}

Information of contraceptive methods also helps to regulate the contraceptive prevalence rate. Affordable and easy access of contraceptive supply would help to increase use of the contraceptive devices. 
Table-3: Percentage distribution for respondents by source of contraceptive methods, 2015

\begin{tabular}{|l|c|c|}
\hline Sources of Contraceptive Devices & Number & Percent \\
\hline Health Workers & 27 & 13.5 \\
\hline Health posts & 49 & 24.5 \\
\hline Friend/neighbours & 12 & 6.0 \\
\hline Husband & 24 & 12.0 \\
\hline Family planning clinics & 88 & 44.0 \\
\hline Total & 200 & 100.0 \\
\hline
\end{tabular}

Source: Field Survey, 2015

Table 3 illustrates that the majority of the sources of contraceptive devices of the respondents obtained family planning clinics (44\%), followed by health posts $(24.5 \%)$, health workers (13.5\%), and husband (12\%) and only less powerful sources of information of contraceptives devices found friends and neighbours $(6 \%)$ in the study area.

\section{Number of Children Ever Born and Use of Family Planning Methods}

Table-4: Distribution of the respondent's by number of children ever born and use of family planning methods, 2015

\begin{tabular}{|l|c|c|c|c|c|c|c|c|c|c|}
\hline \multirow{2}{*}{$\begin{array}{l}\text { Use of } \\
\text { Family } \\
\begin{array}{l}\text { Planning } \\
\text { Methods }\end{array}\end{array}$} & \multicolumn{9}{|c|}{ Number of Children Ever Born } \\
\cline { 2 - 13 } & Number & Percent & Number & Percent & Number & Percent & Number & Percent & Number & Percent \\
\hline Pills & 4 & 8.61 & 17 & 21.79 & 10 & 26.32 & 10 & 28.57 & 41 & 20.5 \\
\hline Injection & 20 & 40.81 & 32 & 41.02 & 6 & 15.78 & 5 & 14.29 & 63 & 31.5 \\
\hline IUD & 3 & 6.12 & 2 & 2.56 & 5 & 13.16 & 5 & 14.29 & 15 & 7.5 \\
\hline Condom & 8 & 16.30 & 15 & 18.75 & 8 & 21.05 & 8 & 22.86 & 39 & 19.5 \\
\hline Norplant & 5 & 10.20 & 5 & 6.41 & 2 & 5.26 & 2 & 5.71 & 14 & 7.0 \\
\hline $\begin{array}{l}\text { Male } \\
\text { sterilization }\end{array}$ & 5 & 10.20 & 3 & 3.85 & 6 & 15.78 & 3 & 8.57 & 17 & 8.5 \\
\hline $\begin{array}{l}\text { Female } \\
\text { sterilization }\end{array}$ & 4 & 8.10 & 4 & 5.12 & 1 & 2.63 & 2 & 5.71 & 11 & 5.5 \\
\hline Total & 49 & 100 & 78 & 100 & 38 & 100 & 35 & 100 & 200 & 100 \\
\hline
\end{tabular}

Source: Field Survey, 2015

Table 4 exhibits that the most popular contraceptive method has been found injection $(31.5 \%)$, followed by pills (22.5\%), condom (19.5\%), male sterilization (8.5\%), IUD (7.5\%), Norplant $(7 \%)$ and female sterilization $(5.5 \%)$ in the study area. There is positive association between 
number of children ever born and use of family planning methods in the study area.

\section{Ever Use of Family Planning Methods}

Use of family planning methods can contribute to a substantial reduction in fertility and reduce the proportion of unwanted pregnancies as well as maternal deaths that would otherwise occur in the absence of contraception in most of the developing countries. The following table shows the distribution of the respondents by ever use of family planning devices in the study area.

Table-5: Percentage distribution of the respondents by ever use of contraceptives devices, 2015.

\begin{tabular}{|l|c|c|}
\hline Ever use of contraceptive devices & Number & Percent \\
\hline Yes & 182 & 91.0 \\
\hline No & 18 & 9.0 \\
\hline Total & 200 & 100.0 \\
\hline Methods & Number & Percent \\
\hline Pills & 44 & 22.0 \\
\hline Injections & 68 & 34.0 \\
\hline IUD & 8 & 4.0 \\
\hline Condoms & 54 & 27.0 \\
\hline Norplant & 8 & 4.0 \\
\hline Male sterilization & 12 & 6.0 \\
\hline Female sterilization & 6 & 3.0 \\
\hline Total & 200 & 100.0 \\
\hline
\end{tabular}

Source: Field Survey, 2015

Table 5 shows that 91 percent of respondents have been ever using at least one family planning method and less percentage of the respondents (9\%) do not use any family planning methods in the study area. This table also shows that 34 percent of the respondents used Injections, followed by Condoms (27\%), Pills (22\%), Norplant (4\%) and IUD (4\%) in the study area.

\section{Age of Women and Current Use of Family Planning Methods}

The age of women and current use of family planning methods varies with the age interval of women. The following table 6 presents the distribution of currently married women who are currently using family planning methods and the distribution of age groups of the respondents in the study area. 
Table-6: Distribution of the respondents of currently using family planning methods and age group of women, 2015.

\begin{tabular}{|l|c|c|c|c|c|c|c|c|}
\hline \multirow{2}{*}{$\begin{array}{l}\text { Current use } \\
\text { of family } \\
\text { planning } \\
\text { methods }\end{array}$} & \multicolumn{7}{|c|}{ Age Group of Women } & \multicolumn{3}{c|}{ Total } \\
\cline { 2 - 10 } & \multicolumn{2}{|c|}{$20-29$} & \multicolumn{2}{|c|}{$30-39$} & \multicolumn{2}{c|}{$40-49$} & \multicolumn{3}{c|}{} \\
\cline { 2 - 10 } & Number & Percent & Number & Percent & Number & Percent & Number & Percent \\
\hline Pills & 2 & 2.04 & 6 & 10.0 & 2 & 4.76 & 10 & 5.0 \\
\hline Injection & 60 & 61.22 & 20 & 33.33 & 10 & 23.81 & 90 & 45.0 \\
\hline Condoms & 2 & 2.05 & 2 & 3.33 & 1 & 2.38 & 5 & 2.5 \\
\hline Norplant & 4 & 4.08 & 2 & 3.33 & 1 & 2.38 & 7 & 3.5 \\
\hline $\begin{array}{l}\text { Female } \\
\text { Sterilization }\end{array}$ & 30 & 30.61 & 30 & 50.0 & 28 & 66.66 & 88 & 44.0 \\
\hline Total & 98 & 100.0 & 60 & 100.0 & 42 & 100.0 & 200 & 100.0 \\
\hline
\end{tabular}

Source: Field Survey, 2015

Out of the 200 respondents, 98 respondents belong to 20-29 years age group, followed by 60 respondents to 30-39 age group and 42 respondents belong to 4049 age group in the study area. Table 6 exhibits that 45 percent of the respondents have been using injections, followed by female sterilization (44\%), Pills (5\%), Norplant (3.5\%) and Condoms (2.5\%) in the study area.

\section{Purpose of Using Family Planning Methods}

The purpose of family planning is to ensure access to preferred contraceptive methods for women and couples. It is essential to secure the well-being and autonomy of women while supporting the health and development of couples. It enables women who wish to limit the size of their family.

Table-7: Distribution of the respondents by the purpose of using contraceptive devices, 2015.

\begin{tabular}{|l|c|c|}
\hline Purpose of using contraceptive devices & Number & Percent \\
\hline Birth spacing & 62 & 31.0 \\
\hline To prevent STDs, HIV and AIDs & 28 & 14.0 \\
\hline To limit the births & 96 & 48.0 \\
\hline Personal reasons & 14 & 7.0 \\
\hline
\end{tabular}

Source: Field Survey, 2015 
Table 7 exhibits that 48 percent of the respondents' purpose of using family planning methods are to limit the births, 31 percent of the respondents are using for birth spacing, 14 percent of respondents are using to prevent STDs, HIV and AIDs and only less percentage of the respondents $(7 \%)$ are using family planning methods for the causes of personal reasons in the study area.

\section{Conclusion}

Family planning services not only improves women's chances of surviving pregnancy and childbirth but also contributes to gender equality, better child health and improved education outcomes, including poverty reduction. It is to be noted that the knowledge of family planning methods among currently married women of reproductive age group is obtained almost universal. Family planning clinics, health posts and, health workers are major sources of contraceptive devices in the study area. Most of the respondents have found positive attitude towards family planning methods. The main reason for using family planning methods is found for limiting births and birth spacing. The main reason for non-using family planning methods is the cause of desire for more children and husband's disagreement. The information of family planning methods has increased with the increase of the level of education of the respondents. At present, few women feel shyness to discuss about contraceptives devices in the study area. This study also reveals that injection, pills, condoms and female and male sterilization are widely used methods of family planning in the study area.

\section{References}

Central Bureau of Statistics (CBS). (2014). Population Monograph of Nepal 2011, Vol. I. Kathmandu: National Planning Commission Secretariat, Central Bureau of Statistics, Nepal.

Central Bureau of Statistics (CBS). (2014). Population Monograph of Nepal 2011, Vol. II. Kathmandu: National Planning Commission Secretariat, Central Bureau of Statistics, Nepal.

Central Bureau of Statistics (CBS). (2014). Population Monograph of Nepal 2011, Vol. III. Kathmandu: National Planning Commission Secretariat, Central Bureau of Statistics, Nepal.

Ministry of Health and Population (MoHP). (2007). Nepal emography and health survey, 2006. Kathmandu: Ministry of Health and Population, New ERA and Macro International Inc., Nepal.

Ministry of Health and Population (MoHP). (2007). Nepal emography and health survey, 2006. Kathmandu: Ministry of Health and Population, New ERA and Macro International Inc., Nepal. 
Ministry of Health and Population (MoHP). (2012). Nepal demographic and health survey 2011. Kathmandu: Ministry of Health and Population, New ERA and ICF International, Nepal.

Ministry of Health (MoH). (2017). Nepal demography and health survey, 2016. Kathmandu: Ministry of Health, New ERA and ICF, Nepal.

United Nations (UN). (1995). Report of the international conference on population and development Cairo, 5-13 September, 1994. New York: United Nations, United States.

World Health Organization (WHO). (2010). Population Bulletin, 2010. Kathmandu: World Health Organization, Nepal. 